\title{
Comparison of sheep and goats under stall-feeding conditions : roughage intake and feed selection
}

\author{
E. OWEN, R. WAHED \\ Department of Agriculture and Horticulture \\ University of Reading, Earley Gate, Reading, Berks, RG6 2AT, U.K.
}

Three experiments, each with 10 near-adult castrated males per species, were conducted to test the hypothesis that goats eat more than sheep and that goats are more selective feeders than sheep.

In Experiment 1 with long lucerne (Medicago sativa) hay over 14 days, intake of dry matter (DM) per $\mathrm{kg}$ metabolic live weight ( $\mathrm{W}^{0.75}$ ) day (d) was $75.9 \mathrm{~g}$ for sheep, and $83.7 \mathrm{~g}$ for goats, with standard error of difference (sed) 4.7. Hay refusals (21 p. 100 of offered) of goats contained more nitrogen $(\mathrm{N})(23 \vee 16 \pm 2.1 \mathrm{~g} / \mathrm{kg} \mathrm{DM})$ and less acid detergent fibre (ADF) $(449$ v $466 \pm 20.0 \mathrm{~g} / \mathrm{kg} \mathrm{DM})$. Hay offered contained $28 \mathrm{~g} \mathrm{~N}$ and $391 \mathrm{~g} \mathrm{ADF} / \mathrm{kg} \mathrm{DM}$.

In Experiment 2 with ammonia-treated barley straw over 21 days, intake of goats was higher than sheep $(57.7 \times 45.3 \pm 4.9 \mathrm{~g} \mathrm{DM} / \mathrm{kg}$ W0.75 d). Straw refusals $(25 \mathrm{p} .100 \mathrm{of}$ offered) were not significantly different between species $(600$ and $612 \pm 6.4 \mathrm{~g} \mathrm{ADF} / \mathrm{kg} \mathrm{DM}$ for goats and sheep respectively). Both sheep and goats showed some selection as straw offered contained $567 \mathrm{~g} \mathrm{ADF} / \mathrm{kg}$ DM. Experiment 3 followed Experiment 2, with the same animals.

In Experiment 3 over 10 days, ammonia-treated straw and stinging nettle (Urtica dioica L.) were fed ad libitum. Total intake was higher for goats than sheep $(75.2 \mathrm{v}$ $\left.65.6 \pm 4.6 \mathrm{~g} \mathrm{DM} / \mathrm{kg} \mathrm{W}^{0.75} \mathrm{~d}\right)$ and goats adapted more rapidly to introduction of the new feed (stinging nettle) than sheep. Refusal compositions showed similar trends to Experiments 1 and 2 .

The experiments confirm that for near-adult castrated animals, goats consume more roughage than sheep. The consistent trend for goat feed refusals to contain less acid detergent fibre and more nitrogen than those of sheep confirms popular belief that goats prefer coarse roughage.

Key words : Goat, sheep, roughage, intake, fced selection.

\section{Use of goats as a way for discriminating the palatability of concentrate feeds}

\author{
P. MORAND-FEHR, J. HERVIEU, A. GUTTER, D. LEGENDRE
}

Station de Nutrition et Alimentation (I.N.R.A.) de l'I.N.A.P.G. 16, rue Claude-Bernard, 75231 Paris Cedex 05

The ability of goats to select the most nutritive parts of foragcs or feeds is higher than that of the other ruminants (MORAND-FEHR et al., 1979). It was used in this experiment for discriminating the palatability of concentrate feeds.

Fourtcen goats of an experimental flock were selected for cafcteria tests on their acceptability of various feeds.

Several trials were made previously to determine experimental conditions. Each goat was given two feeds simultaneously. Each feed was put in two little cans containing $200 \mathrm{~g}$ 